\title{
ANALISIS PENERAPAN METODE SAW PADA PERANCANGAN SISTEM PENDUKUNG KEPUTUSAN PEMILIHAN JUDUL SKRIPSI BERDASARKAN PENJURUSAN
}

\author{
Fryda Fatmayati ${ }^{1}$ \\ ${ }^{1}$ Sekolah Tinggi Teknologi Kedirgantaraan \\ ${ }^{1}$ fryda.fatmayati@sttkd.ac.id
}

\begin{abstract}
Abstrak
Sistem pendukung keputusan menghasilkan suatu solusi permasalahan dari kriteria-kriteria, alternatif dan bobot yang digunakan. Pada penelitian ini menggunakan studi kasus pemilihan judul skripsi berdasarkan jurusan yang dapat menghasilkan solusi penentuan judul skripsi. Metode yang digunakan pada penelitian ini adalah metode Simple Additive Weighting. Hasil penelitian ini menunjukan bahwa penentuan judul skripsi didasarkan pada penjurusan MTU002 bidang Manajemen Perusahaan dengan nilai 0,786.
\end{abstract}

Kata kunci : Decision Support System, Simple Additive Weighting, Judul Skripsi

\section{Pendahuluan}

Perkembangan dunia pendidikan saat ini sudah berkembang sangat pesat. Hal ini dibuktikan dengan semakin banyaknya perguruan tinggi yang berdiri baik negeri maupun swasta di setiap provinsi. Salah satu perguruan tinggi swasta yang berada di Provinsi Daerah Istimewa Yogyakarta adalah Sekolah Tinggi Teknologi Kedirgantaraan (STTKD).

Sekolah Tinggi Teknologi Kedirgantaraan (STTKD) merupakan perguruan tinggi swasta yang bergerak di bidang kedirgantaraan dan berdiri pada tanggal 1 Oktober 1994. Tujuan didirikannya STTKD adalah untuk mengembangkan dan menyebarluaskan ilmu pengetahuan di bidang penerbangan secara sistematis dan ilmiah melalui penyelenggaraan pendidikan yang berkualitas. STTKD terdiri dari enam program studi, yaitu S1 Teknik Dirgantara, D-IV Manajemen Transportasi Udara, D-III Manajemen Transportasi, D-III Aeronautika, D-I Pramugari dan D-I Ground Handling (Proposal PP PTS Profil Sekolah Tinggi Teknologi Kedirgantaraan. 2015).

Pada penelitian ini mengambil studi kasus pada Program Studi D-IV Manajemen Transportasi Udara yang terdapat STTKD. Taruna dan taruni di Program Studi D-IV diwajibkan untuk menyelesaikan skripsi sebagai syarat kelulusan. Dalam penyusunan skripsi, judul skripsi merupakan menjadi hal yang sangat penting. Pada saat bimbingan skripsi dilaksankaan banyak dosen pembimbing yang masih mengalami kesulitan dalam menentukan judul skripsi yang sesuai dengna minat dan tema kedirgantaraan. Setiap judul skripsi harus sesuai dengan pengujian hipotesis yang diambil. Dosen pembimbing juga masih mengalami kesulitan dalam menentukan pengujian hipotesis dengan judul skripsi taruna-taruni. Tujuan penelitian ini membantu dalam menentukan judul skripsi berdasarkan dari penjurusan yang ada di program studi.

Penelitian yang telah dilakukan oleh Gunawan, Indah Lestari, Muhammad Ihsan Zul (2015) melakukan penelitian tentang sistem pendukung keputusan pemilihan pembimbing dan penguji proyek akhir di Politeknik Caltex Riau. Sistem pendukung keputusan ini menggunakan metode Text Mining, k-Nearest Neighbor ( $k-\mathrm{NN})$ dan SAW (Simple Additive Weighting). Hasil penelitian ini merekomendasikan 5 nama dosen yang memiliki bobot tertinggi untuk menjadi pembimbing dan penguji PA berdasarkan KBK judul PA mahasiswa.

\section{Metodologi}

\subsection{Sistem Pendukung Keputusan}

Sistem pendukung keputusan sebagai sistem berbasis komputer yang terdiri dari tiga komponen yang saling berinteraksi, sistem bahasa (mekanisme untuk memberikan keputusan lain), sistem pengetahuan (respositori pengetahuan domain masalah yang ada pada sistem pendukung keputusan atau sebagai data atau prosedur) dan sistem pemrosesan masalah (hubungan antara dua komponen lainnya, terdiri dari satu atau lebih kapasitas manipulasi masalah umum yang diperlukan untuk mengambil keputusan). SPK membahas masalah terstruktur, semi terstruktur serta mendukung beberapa keputusan yang saling berinteraksi (Kusrini, 2007:1). 


\subsection{Metode Simple Additive Weighting (SAW)}

Metode Simple Additive Weighting (SAW) merupakan metode yang paling dikenal dan paling banyak digunakan orang dalam menghadapi situasi Multiple Attribute Decision Making (MADM), MADM itu sendiri merupakan suatu metode yang digunakan untuk mencari alternatif optimal dari sejumlah alternatif dengan kriteria tertentu. Metode ini mengharuskan pembuat keputusan menentukan bobot bagi setiap atribut. Skor total untuk sebuah alternatif diperoleh dengan menjumlahkan seluruh hasil perkalian antara rating (yang dapat dibandingkan lintas atribut) dan bobot tiap atribut. Rating tiap atribut haruslah bebas dimensi dalam arti telah melewati proses normalisasinya sebelumnya (Basyaib, 2006:135).

Dalam menyelesaikan kasus menggunakan metode SAW, ada beberapa langkah yang harus dikerjakan, yaitu (Kusumadewi, 2006):

1. Menentukan kriteria-kriteria yang akan dijadikan acuan dalam pengambilan keputusan.

2. Menentukan rating kecocokan setiap alternatif pada setiap kriteria.

3. Membuat matriks keputusan berdasarkan kriteria, kemudian melakukan normalisasi matrik berdasarkan persamaan yang disesuaikan dengan jenis atribut sehingga diperoleh matriks normalisasi R.

4. Hasil akhir diperoleh dari proses perangkingan yaitu penjumlahan dari perkalian matriks ternormalisasi $\mathrm{R}$ dengan vector bobot sehingga diperoleh nilai terbesar yang dipilih sebagai alternatif terbaik (A) sebagai solusi.

Berikut merupakan formula untuk melakukan normalisasi, yaitu :

$$
r i j=\left\{\begin{array}{l}
\frac{x i j}{\max ^{x i j}} \\
\frac{\min ^{x i j}}{x i j}
\end{array}\right.
$$

Keterangan :

Rumus pertama : jika $j$ adalah attribut keuntungan (benefit)

Rumus kedua : jika j adalah attribut biaya (cost)

Dimana :

rij = rating kinerja ternormalisasi

Maxij = nilai maksimum dari setiap baris dan kolom

Minij = nilai minimum dari setiap baris dan kolom

$\mathrm{Xij} \quad=$ baris dan kolom dari matriks

Dengan rij adalah rating kinerja ternormalisasi dari alternatif Ai pada atribut $\mathrm{Cj} ; \mathrm{i}=1,2, \ldots, \mathrm{m}$ dan $\mathrm{j}=$ $1,2, \ldots, \mathrm{n}$.

Nilai preferensi untuk setiap alternatif (Vi) diberikan sebagai :
Dimana :

$$
v i=\sum_{j=1}^{n i} w i r i j
$$

vi = nilai akhir dari alternatif

wj = bobot yang telah ditentukan

rij $\quad=$ normalisasi matriks

Nilai vi yang lebih besar mengindikasikan bahwa alternatif Ai lebih terpilih.

\section{Hasil dan Analisis}

Dalam mengambil keputusan beberapa kriteria dan alternatif. Di bawah ini akan dijelaskan mengenai kriteria-kriteria yang akan digunakan dalam menentukan judul skripsi.

\subsection{Menentukan Kriteria}

Langkah pertama adalah dengan menentukan kriteria yang akan digunakan untuk menentukan judul skripsi.

Tabel 1. Ketentuan Kriteria

\begin{tabular}{|c|l|}
\hline Kode Kriteria & \multicolumn{1}{|c|}{ Ketentuan Kriteria } \\
\hline C1 & On the Job Training (OJT) \\
\hline C2 & Pembaharuan Penelitian \\
\hline C3 & Jumlah mata kuliah minat \\
\hline C4 & Nilai mata kuliah minat penelitian yang \\
\hline C5 & $\begin{array}{l}\text { Kemiripan } \\
\text { relevan }\end{array}$ \\
\hline
\end{tabular}

Sumber : Data olahan (2021)

\subsection{Menentukan Alternatif}

Setelah menentukan kriteria, kemudian menentukan alternatif yang akan digunakan. Alternatif yang digunakan merupakan penjurusan pada program studi berdasarkan bidang keilmuan. Berikut adalah alternatif yang akan digunakan.

Tabel 2. Alternatif

\begin{tabular}{|c|c|}
\hline Kode Bidang & Bidang Keilmuan \\
\hline MTU001 & Airport Operasional \\
\hline MTU002 & $\begin{array}{c}\text { Manajemen Perusahaan } \\
\text { Penerbangan }\end{array}$ \\
\hline MTU003 & Ground Service \\
\hline MTU004 & Pramugari \\
\hline
\end{tabular}

Sumber : Data olahan (2021)

\subsection{Menentukan Nilai Bobot}

Pada langkah ketiga ini memberikan nilai bobot atau tingkatan kepentingan (W) setiap kriteria yang akan digunakan untuk menentukan judul skripsi adalah sebagai berikut.

Tabel 3. Tabel Bobot Preferensi (W) Setiap Kriteria

\begin{tabular}{|c|l|l|}
\hline $\begin{array}{c}\text { Kode } \\
\text { Kriteria }\end{array}$ & Ketentuan Kriteria & $\begin{array}{c}\text { Bobot } \\
\text { Preferensi (W) }\end{array}$ \\
\hline C1 & $\begin{array}{l}\text { On the Job Training } \\
\text { (OJT) }\end{array}$ & $0,30(30 \%)$ \\
\hline C2 & $\begin{array}{l}\text { Pembaharuan } \\
\text { Penelitian }\end{array}$ & $0,15(15 \%)$ \\
\hline C3 & Jumlah mata kuliah & $0,20(20 \%)$ \\
\hline
\end{tabular}


Additive Weight maka didapatkan hasil bahwa penentuan judul skripsi didasarkan pada penjurusan MTU002 bidang Manajemen Perusahaan.

\section{Kesimpulan dan Saran}

\subsection{Kesimpulan}

Dari hasil proses penelitian ini dapat disimpulkan bahwa penentuan judul skripsi berdasarkan jurusan menggunakan metode Simple Additive Weight, didasarkan pada penjurusan MTU002 bidang Manajemen Perusahaan dengan nilai 0,786.

\subsection{Saran}

Pengembangan yang dapat dilakukan dari penelitian ini, yaitu :

1. Perlu diujikan menggunakan metode selain metode Simple Additive Weight.

2. Dapat dilakukan penelitian dengan cara komparasi lebih dari satu metode.

\section{Daftar Pustaka:}

Basyaib, Fachmi. (2006). Teori Pembuatan Keputusan. Jakarta. Grasindo

Kusrini. (2007)[a]. Konsep dan Aplikasi Sistem Pendukung Keputusan. Yogyakarta: Penerbit Andi.

Kusrini. (2007)[b]. Strategi Perancangan dan Pengelolaan Basis Data. Yogyakarta: Penerbit Andi.

Sri Kusumadewi, Sri Hartati, Agus Harjoko. (2006) Fuzzy Multi Atribut Decision Making (Fuzzy MADM). Yogyakarta: Penerbit Graha Ilmu.

Proposal PP PTS Profil Sekolah Tinggi Teknologi Kedirgantaraan. 2015. 